УДК $101+37.013 .2$

DOI: 10.6060/BHIISUCT2021 10

\title{
Зеленцова М.Г.
}

Зеленцова Марина Григорьевна - доктор философских наук, Ивановский государственный химико-технологический университет, профессор кафедры философии. E-mail: marigumm@gmail.com.

\section{ПЕДАГОГИЧЕСКАЯ КОММУНИКАЦИЯ В ЦИФРОВОЙ СРЕДЕ: ФИЛОСОФСКИЕ АСПЕКТЫ}

В статье представлены некоторые философские аргументы в защиту тезиса о необходимости сохранения традиционной формы педагогической коммуникации в системе образования. Эти аргументы связаны с философским пониманием человека как существа сочиального и нравственного, а образования - как обретения человеком собственного образа в прочессе живого диалога педагога и ученика. Отмечены факторы, ведущие к снижению качества образования в случае его перевода в ичифровую среду, в частности, возрастание отчуждённости, механистичности, стандартизированности общения, что в значительной степени обедняет диалог.

Ключевые слова: образование, цифровая среда, коммуникация, философия.

\section{Zelentsova M.G.}

Zelentsova M.G. - Doctor of Philosophy, Professor, Ivanovo State University of Chemistry and Technology. E-mail: marigumm@gmail.com.

\section{PEDAGOGICAL COMMUNICATION IN THE DIGITAL ENVIRONMENT: PHILOSOPHICAL ASPECTS}

The article presents some philosophical arguments in defense of the idea of the necessity to preserve the traditional form of pedagogical communication in the education system. These arguments are associated with the philosophical understanding of man as a social and moral being, and education - as a person acquiring his own image in the process of a living dialogue between a teacher and a student. The factors leading to a decrease in the quality of education in the case of its transfer to a digital environment are noted, in particular, an increase in alienation, mechanicalness, standardization of communication, which significantly weaken the dialogue.

Key words: education, digital environment, communication, philosophy.

Коммуникацию принято рассматривать как одну из форм связи между людьми, содержанием которой являются общение и передача информации. Иногда различают коммуникацию как процесс передачи информации (например, с помощью масс-медиа) и коммуникацию как процесс общения (межличностное общение). По своим целям, средствам и результатам эти процессы действительно различны. 
Межличностное общение - это творческий процесс. В отличие от коммуникации как информационной связи субъекта с объектом, общение симметрично, в нем нет отправителя и получателя информации, управляющего и управляемого, а есть собеседники, участники диалога, партнеры по совместной выработке информации. Это отношение носит субъект-субъектный характер (Я - Ты). Кроме того, общение в своей основе - это нравственный процесс, оно не существует без уважения и любви к другому человеку и этим тоже отличается от коммуникации как механической трансляции информационных сообщений.

Педагогическая коммуникация характеризуется единством процессов межличностного общения (педагога и ученика) и передачи информации. Это единство имеет принципиальное значение для эффективного образования и воспитания. С точки зрения философии, образование - это не просто приобретение определенной суммы знаний, умений и навыков. В античной Греции образование рассматривалось как культивирование человеческого в человеке (пайдейя). Задача образования формирование целостной, всесторонне развитой личности. Традиции античности были продолжены философами-гуманистами эпохи Возрождения и Просвещения, которые понимали образование как «функцию жизни» человека, как смысловое вхождение индивида в мир культуры и постижение им смысла собственного бытия. Георг Гегель говорил об образовании как о восхождении отдельного человеческого существа к своей всеобщей природе. Образование есть обретение человеком собственного образа во всей его полноте, уникальности и индивидуальности. В таком понимании, модель образования - это модель человека.

Какова общая природа человека? Философия - от античности и до наших дней определяет человека как существо социальное, стремящееся к единству с миром, с другими людьми и с самим собой. Философы отмечали и другие специфические особенности человека: разум, труд, символотворчество, нравственность, способность к познанию, но все эти особенности выводились из социальности, или иначе, из диалогической природы человека. Известный германский философ XX века Мартин Бубер, представитель «диалогического персонализма», различает два вида отношений человека к миру. Первое отношение - «Я - Оно», в котором человек воспринимает мир и других людей как безличные объекты, предназначенные для утилитарного использования, манипуляции и контроля. Второе отношение - «Я - Ты», в котором устанавливаются неотчужденные, одухотворенные связи между человеком и его окружением, основанные на любви. Согласно Буберу, истинное бытие человека - это диалог [2].

$\mathrm{B}$ российской философии идею диалогичности человека (и диалогичности гуманитарных наук) наиболее ярко выразил Михаил Бахтин. Он утверждал единство сознания личности и сознания культуры в целом, создаваемое в их диалоге. «...Вся культура в целом интегрируется в едином и единственном контексте жизни, которой я причастен. Интегрируется и культура в целом, и каждая отдельная мысль, каждый отдельный продукт живого поступка в единственном индивидуальном контексте действительного событийного мышления», - писал Бахтин [1, с. 108]. «Участное» сознание, по мысли Бахтина, несет в себе общее, универсальное содержание. Человек мыслит и поступает как общественное существо, как представитель определенной эпохи и культуры, носитель коллективных смыслов и ценностей. Единичное сознание формируется в двуедином процессе: оно отражает общезначимые ценности, интериоризирует и перерабатывает их, обогащает их индивидуальными смыслами и возвращает назад в ответственном акте-поступке [1, с. 108].

Единичное сознание несет в себе универсальное содержание не только потому, что познающий и оценивающий субъект есть представитель определенной культуры, 
но и потому, что он - человек, то есть родовое существо, закономерно детерминированное в своей жизнедеятельности собственной человеческой природой и внешними природными факторами. О социальном характере общей природы человека размышляет Юрген Хабермас, известный своими исследованиями в области социальной коммуникации. Он отмечает, что именно коммуникативное действие превращает в действительность заложенную в человеке возможность (и потребность) социально-нравственного развития. Хабермас выступает против манипуляций с геномом человека, которые могут разрушить его формировавшуюся в течение тысячелетий видовую природу - «коммуникативно структурированную жизненную форму» [6, с. 86].

Возможно, такое понимание человека устарело? Весьма распространенной является точка зрения, согласно которой современная информационная эпоха создала другой тип личности - личности, все меньше нуждающейся в непосредственном общении, живущей в интернет-пространстве и прекрасно при этом себя чувствующей. Однако психологи констатируют рост депрессивных состояний у подростков и взрослых, много времени проводящих в социальных сетях, усиливающееся чувство изоляции, одиночества, рост числа самоубийств и т. п. Очевидно, что биологически и психологически человек остается все тем же Homo Sapiens, каким он был тысячи лет назад, а потребность в межличностном общении по-прежнему является его сущностной потребностью. Как отмечает Эрих Фромм, человек может меняться в связи с изменением экономической и социальной структуры общества, но его приспособляемость не безгранична. Существуют неотъемлемые психологические свойства человека (такие же императивные, как и физиологические потребности), которые нуждаются в удовлетворении. Важнейшая из них - потребность в объединении с миром, с другими людьми, в общении. Существуют также потребности в росте и развитии, в творческом мышлении, в эстетическом восприятии действительности и др. [5]. Эти общие тенденции являются психологическим эквивалентом аналогичных биологических тенденций, то есть, они генетически детерминированы, на что со всей определенностью указывает современная эволюционная биология, в частности, социобиология и эволюционная теория познания.

Модель человека как существа социального влечет за собой соответствующую модель педагогической коммуникации как, прежде всего, непосредственного межличностного общения педагога и ученика, живого диалога, от качества которого в значительной степени зависит и формирование личности ученика, и усвоение передаваемой педагогом информации. Это означает, что информационная составляющая педагогической коммуникации менее важна, чем межличностное общение. Особенно актуален такой подход для философии и других гуманитарных наук. Специфика философского и гуманитарного знания состоит в его диалогичности, мультипарадигмальности, отнесенности к ценностям, мировоззренческой направленности. Главный метод обучения и развития творческих способностей личности в философии - это «сократическая беседа», в ходе которой педагог задает наводящие вопросы, помогающие ученику размышлять над сложными философскими проблемами, видеть логические ошибки в своих рассуждениях, высказывать собственную точку зрения и делать правильные выводы. Согласно Платону, такая беседа пробуждает душу и хранящиеся в ней знания-воспоминания о ее пребывании в мире чистых сущностей (идей, эйдосов), способствует интеллектуальному и нравственному совершенствованию человека. Что касается гуманитарных наук, то главным методом познания здесь является герменевтический метод, направленный на раскрытие и постижение смыслов изучаемых текстов, на диалог с автором. Он дает возможность развить не только мышление, но и способность к эмпатии, 
сопереживанию, пониманию, без чего знание остается поверхностным и механическим. Информация становится подлинным знанием только тогда, когда она осмыслена, прочувствована, оценена, сопоставлена с предшествующим опытом индивида и проработана в межличностном общении.

Возможно ли полноценное межличностное общение в цифровой образовательной среде? Каковы очевидные риски перевода значительной части образовательного процесса в электронный режим? На наш взгляд, общение, опосредованное электронной техникой, снижает эффективность педагогической коммуникации как диалога по нескольким причинам.

Человек - существо социальное, его мозг - это, прежде всего, социальный орган, то есть, он формируется и развивается в общении. Познание - это коллективный процесс, важными составляющими которого являются свободный обмен мнениями, поддержка (учебной) группы, сопереживание, эмоциональный отклик. Согласно нейробиологу и психиатру Манфреду Шпитцеру, наши социальные навыки - умение сопереживать, поставить себя на место другого человека и т. п. - способствуют развитию и увеличению участков головного мозга, ответственных за мышление (фронтального кортекса), и, соответственно, когнитивных способностей. Головной мозг растет вместе с социальным окружением. Поэтому, считает Шпитцер, образование должно проходить в реальном, а не в виртуальном мире [7].

Живое общение способствует выработке гормонов удовольствия. Дофамин создает чувство радости от того, что человек находит что-то необходимое, например, решение сложной задачи. Но этой радостью он должен поделиться с другими. Серотонин создает чувство социальной значимости, признания. Окситоцин дает чувство безопасности в среде себе подобных. Как известно, положительные эмоции способствуют лучшему усвоению знаний. Но как передать эмоции в виртуальной среде?

Человек - существо телесное, поэтому для ощущения достоверности собственного бытия, складывающегося из чувства определенности границ нашего тела, различимости нашего голоса, утвержденности нашего Я в пространстве социальных отношений, нам необходимы другие люди. Человеческий организм как биофизический объект излучает различного вида волны: микроволны СВЧ, электромагнитные волны, инфракрасные, акустические (фононы), оптические (аура), тепловые волны. Мы излучаем тепло или холод, сочувствие или презрение и воспринимаем эти эмоции благодаря телесному контакту (в широком смысле слова), например, благодаря жестам или взглядам. Наиболее адекватно передавать эмоции можно только в процессе непосредственного общения. Как отмечает психолог Росс Кэмпбелл, чтобы передать сочувствие и любовь, необходимо, прежде всего, пристальное внимание, контакт глаз и физический контакт [4]. То же, по-видимому, относится и к знаниям. Передавать знания без любви и уважения к ученику невозможно. Работая в электронной среде, педагог не видит глаза студентов, пристальное внимание к каждому ученику удается реализовывать с трудом, а физический контакт вообще невозможен. Это приводит к снижению эффективности обучения и воспитания.

Человек - не только чувствующее, но и «моторное» существо. Это означает, что в процессе обучения огромную роль играют не только чувственные восприятия, например, зрительное, но и движения, прежде всего, движения руки. Согласно современным нейробиологическим исследованиям, примерно треть коры нашего головного мозга служит зрению, другая треть отвечает за планирование и выполнение движений (за все остальное отвечает последняя треть). У детей большую роль в научении играет не только чувственность приобретаемых ими опытных знаний о мире, но и деятельное общение с миром [7, с. 145]. Такое же деятельное общение 
осуществляет и студент, находящийся в аудитории на лекциях и семинарах и ведущий записи рукой, что значительно эффективнее для обучения и запоминания материала, чем печатание на клавиатуре или простое прослушивание или прочтение электронного текста. Обучение должно продвигаться с использованием сердияа, мозга и руки, как полагал уже Иоганн Генрих Песталоцци, оно должно проходить на реальных вещах в реальном мире. И такой подход неверно считать устаревшим. Само понятие «схватывание сути», означающее глубокое познание вещей, связано с движением человеческой руки.

Еще один важнейший аспект полноценного межличностного общения - это аспект нравственный. Нравственность (мораль) выступает как квинтэссенция человеческой социальности, поскольку она направлена на сохранение общества как целого и одновременно на сохранение индивидов как его частей. Существование общества возможно лишь тогда, когда его интересы приведены в гармонию с интересами отдельной личности. Именно это является главной целью морали и моральным идеалом. Этот моральный идеал выражен в этических категориях долга и гуманности, представляющих основной моральный закон, или основное моральное отношение. Основной моральный закон требует относиться к благу общества как к первичной цели (долг), к благу личности как конечной цели (гуманность), а к их единству как к высшей цели (3).

Задатки моральных чувств человека являются врожденными, но в целом моральное сознание личности представляет собой плод общественного воспитания и образования. Поэтому вопрос о влиянии электронной образовательной среды на моральные ценности также требует анализа. Практика показывает, что при переводе педагогической коммуникации из реального пространства в виртуальное межличностное общение все больше уступает место информационному процессу как субъект-объектному отношению. Общение, опосредованное электронными техническими средствами, несет на себе неизгладимый отпечаток отчужденности, механистичности, стандартизированности. И педагог, и студент неизбежно начинают воспринимать друг друга не как живых личностей, а как виртуальных персонажей, роботизированных существ, служащих для достижения сугубо прагматических целей. Но, относясь к другому человеку как к объекту, человек сам превращается в объект, «овнешняется», становится вещью, теряет человечность. Утилитаристская установка сознания ведет к игнорированию морали, к разрушению основных моральных мотивов - долга (ответственности) и гуманности (сочувствия, благодарности), поскольку роботу нет смысла говорить «спасибо» или отвечать перед ним за свои поступки, он служит только средством, объектом потребления. Деградация морали, в свою очередь, негативно влияет на уровень психической активности личности, снижает ее познавательную и творческую продуктивность, способность к обучению.

Таким образом, элиминация человеческой социальности, телесности и нравственности из сферы педагогической коммуникации в результате ее перевода в цифровую среду в значительной степени обедняет диалог студента и педагога, приводит к снижению качества образования в целом. На наш взгляд, традиционные формы педагогической коммуникации должны быть сохранены, а использование электронных средств в системе образования должно осуществляться в разумных пределах..

\section{СПИСОК ЛИТЕРАТУРЫ}

1. Бахтин М.М. К философии поступка // Философия и социология науки и техники. Ежегодник 1984-1985. М.: Наука, 1986. С. 80-160.

2. Бубер М. Я и Ты. М.: Высшая школа, 1993. 174 с. 
3. Гумницкий Г.Н. Основы этики. Монография. Иваново: ИвГПУ, 2016. 132 с.

4. Кэмпбелл Р. Как на самом деле любить детей. М.: Знание, 1992. 188 с.

5. Фромм Э. Душа человека. М.: Республика, 1992. 430 с.

6. Хабермас Ю. Будущее человеческой природы. М.: «Весь Мир», 2002. 144 с.

7. Шпитцер М. Антимозг. Цифровые технологии и мозг. М.: АСТ, 2014. 288 с..

\section{REFERENCES (TRANSLITERATED)}

1. Bahtin M.M. K philosophii postupka // Philosophija I sociologija nauki I tehniki. Ezgegodnik 1984-1985. M: Nauka, 1986. S. 80-160.

2. Buber M. Ja I Ty. M.: Vysshaja shkola, 1993. $174 \mathrm{~s}$.

3. Gumnickij G.N. Osnovy etiki. Monographija. Ivanovo: IvGPU, 2016. $132 \mathrm{s.}$

4. Kempbell R. Kak na samom dele lubit detej. M.: Znanije, 1992. $188 \mathrm{~s}$.

5. Phromm E. Dusha cheloveka. M.: Respublika, 1992. $430 \mathrm{~s}$.

6. Habermas U. Budushee chelovecheskoj prirody. M.: Ves mir, 2002. $144 \mathrm{~s}$.

7. Shpitcer M. Antimozg. Ciphrovyje texnologii I mozg. M.: AST, 2014. 288 s.

Поступила в редакцию 15.06.2021 г. Принята к публикации 01.07.2021 г.

Для циитирования:

Зеленцова М.Г. Педагогическая коммуникация в цифровой среде: философские аспекты // Вестник Гуманитарного института. 2021. №2. С. 10-15.

URL: https://isuct-bhi.ru/sites/default/files/issue/2021/1/bhi-2021-1-010.pdf 